Maurer School of Law: Indiana University

Digital Repository@Maurer Law

Indiana Law Journal

Volume 1 | Issue 1

Article 1

$1-1926$

\title{
Effect of an Unconstitutional Statute
}

Oliver P. Field

Indiana University

Follow this and additional works at: https://www.repository.law.indiana.edu/ilj

Part of the Constitutional Law Commons, and the State and Local Government Law Commons

\section{Recommended Citation}

Field, Oliver P. (1926) "Effect of an Unconstitutional Statute," Indiana Law Journal: Vol. 1 : Iss. 1 , Article 1. Available at: https://www.repository.law.indiana.edu/ilj/vol1/iss1/1

This Article is brought to you for free and open access by the Law School Journals at Digital Repository @ Maurer Law. It has been accepted for inclusion in Indiana Law Journal by an authorized editor of Digital Repository @ Maurer Law. For more information, please contact rvaughan@indiana.edu.

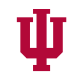

JEROME HALL LAW LIBRARY

INDIANA UNIVERSITY

Maurer School of Law
Bloomington 


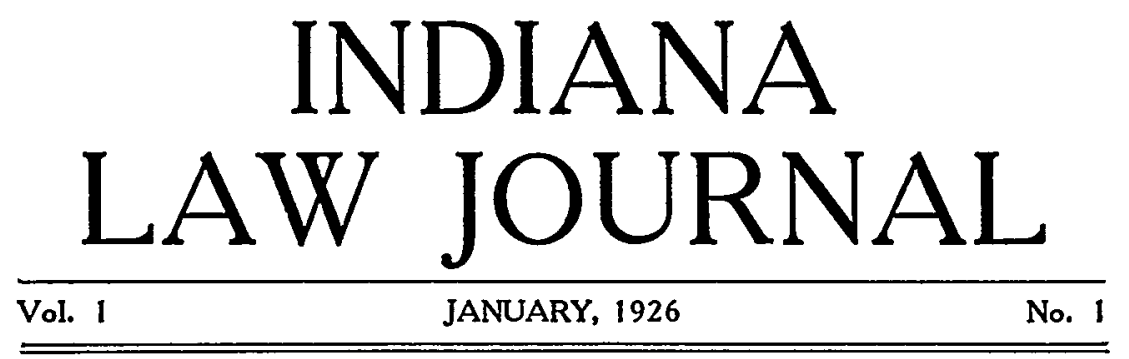

\section{EFFECT OF AN UNCONSTITUTIONAL STATUTE}

\section{OLIVER P. FIELD*}

What is the effect upon a statute of a judicial decision that the statute is unconstitutional? What of the acts of persons who have relied on the statute before the decision of unconstitutionality was rendered? The practical effect of the answers which are to be given to these questions may be illustrated by two types of cases which have been before the courts of Indiana or the courts of other states. Suppose in the first place that an officer arrests a person by virtue of authority granted in a statute. The person arrested attacks the constitutionality of the statute. The court decides that the statute is unconstitutional. Then the person who has been arrested brings an action of damages against the officer. Can the officer plead the statute under which he acted, in justification for his act? Suppose in the second place that a municipality floats a bond issue. The statute under which the bonds are issued is assailed in the courts and they decide that it is constitutional. Six months later the state court decides that the statute is unconstitutional, and reverses their former decision. Can the holder of the bonds recover in an action against the eity? Does a declaration of unconstitutionality have the effect of repealing a statute or does the statute become inoperative from the time of the decision which declares it unconstitutional, or is the statute to be considered void $a b$ initio from the date of the purported enactment of it by the legislature? It is with the answers which the courts have given to these questions and others which have been presentd by actual cases that the writer will deal. This paper will consider only those cases involving total unconstitutionality and will not attempt to handle the cases of partial unconstitutionaliy. ${ }^{2}$

The Supreme Court of Indiana has said that if a statute is unconstitutional it "is no law, and cannot be used to give appellee a right of action against appellant." ${ }^{2}$ And again, in passing upon an amend-

* See biographical note p. 32 .

1 On the effect of partial unconstitutionality see 15 R. C. L. secs. 121-133; Note, Ann. Cas. 1916 D 89; Cooley, Constitutional Limitations (5 ed.) 211216.

2 Bedford Quarries v. Bough, (1907) 168 Ind. 671, 80 N. E. 539, 14 I. R. A. 418. 
ment to a statute which was held to be unconstitutional, the court said in Carr v. State,

"An act which violates the Constitution has no power and can, of course, neither build up or tear down. It can neither create new rights nor destroy existing ones. It is an empty legislative declaration without force or vitality."

In accordance with the views expressed above it is held in Indiana that a repealing act which is unconstitutional can have no effect upon the statute sought to be repealed and the previous statute remains the law as though the legislature had not made any attempt to change it. ${ }^{4}$ In the very interesting case of Johnson v. The Board etc., ${ }^{5}$ in which a statute was held unconstitutional because it impaired the obligation of contracts, the court was asked to pass upon the question whether fraud had been used in the procurement of the passage of the statute in the legislature. The court refused to pass upon this point because it was clear that if no statute whatever had been passed no question of fraud could have arisen. The statute before the court was unconstitutional. An unconstitutional statute is absolutely void and to be considered as though it had never been passed. Therefore, the court argued, no question of fraud could arise in connection with this statute.

That an unconstitutional statute is to be considered as though it had never been enacted by the legislature is also the view of a number of other courts. For example, the United States Supreme Court has said, ${ }^{6}$

"That act was therefore as inoperative as if it had never been passed, for an unconstitutional act is not a law, and ean neither confer a right or immunity nor operate to supersede any existing valid law." And an appellate court of Texas ${ }^{7}$ has said that an unconstitutional statute "is of no more force or validity than a piece of blank paper," while the Minnesota court ${ }^{8}$ has expressed the same idea by stating that it "is

3 (1890) 127 Ind. 204, 26 N. E. 778; 11 L. R. A. 370.

4 Igoe v. State, (1860) 14 Ind. 239; Grubbs v. State, (1865) 24 Ind. 295. See also Oolitic Stone Co. of Ind. v. Ridge, (1900) 169 Ind. 639, 91 N. E. 944.

5 (1894) 140 Ind. 152, 39 N. E. 311.

- Chicago, Indianapolis \& Louisville Ry. v. Hackett, (1912) 227 U. S. 559, S. Ct., 57 L. Ed. 966. See also Louisiana v. Pillsbumy, (1881) 15 Otto 287, 26 L. Ed. 1090, where the court said in the course of an opinion declaring a state statute unconstitutional because impairing the obligation of contracts, "Legislation of a state thus impairing the obligation of contract made under its authority, is null and void; and the courts in enforcing the contracts will pursue the same course and apply the same remedies as though such invalid legislation had never existed." Gunn v. Barry, (1872) 15 Wall. 610, 21 L. Ed. 212 ; 12 C. J. 800-1.

7 Ex parte Bockhorn, (1911) 62 Tex. Cr. 651, 138 S. W. 706.

${ }^{8}$ Minn. Sugar Co. v. Iverson, (1903) 91 Minn. 30, 97 N. W. 454. See also Finders v. Bodle, (1899) 58 Neb. 57, 78 N. W. 480; State of Kans. v. Bankers \& Mutual Benefit Assn., (1880) 23 Kan. 355; Boales v. Ferguson, (1898) 55 Neb. 565, 76 N. W. 18; City of Henderson v. Lieber's Exr's., (1917) $175 \mathrm{Ky}$. 15, 192 S. W. 830. 
simply a statute in form, is not a law, and under every circumstance or condition lacks the force of law."

In accord with this doctrine that a statute which is declared wnconstitutional is roid $a b$ initio it has been held that a person aceused of a crime and convicted under an unconstitutional statute is entitled to a reversal and as a consequence, his freedom. ${ }^{9}$ This is true even though the accused pleaded guilty, ${ }^{10}$ and even though the defective statute related only to the term of court at which the accused was tried, ${ }^{11}$ having no relation to the substantive law under which he was tried. The same rule has been applied to judgments rendered by a court in civil cases. ${ }^{12}$ It has also been held that unconstitutional statutes which purported to incorporate ${ }^{13}$ or disincorporate ${ }^{14}$ municipalites fail entirely to accomplish their purpose and as a result of this the taxes which are paid to the city may be recovered. ${ }^{15}$ However, it should be noted that the courts have gone far to defeat the recovery of taxes paid under statutes which prove to be unconstitutional by holding that if the taxes were paid voluntarily they cannot be recovered. $^{16}$ If the taxes were paid involuntarily, however, they may be recovered.

- Norwood v. State, (1924) Miss. 101 So. 366; Brewer v. State, (1905) Ala. 39 So. 927; State v. Greer, (1924) Fla. 102 So. 739; Ex parte Siebold, (1879) 100 U. S. 376, 25 L. Ed. 719; Candy v. State, (1909) 162 Ala. 678, 49 So. 801; McFarlin v. State, (1909) 123 S. W. 133.

${ }^{10}$ Norwood $v$. State, (1924) Miss, 101 So. 366.

11 Ex parte State ex rel. Smith v. Thurman, (1921) Ala. 88 So. 899.

12 Yellow Pine Lmbr. Co. v. Randall, (1905) 145 Ala. 653, 39 So. 565.

${ }_{13}$ Campbell v. Bryant, (1905) 104 Va. 509, 52 S. E. 638.

14 Ringling $v$. Hempstead, (1911) 193 Fed. 600. It should be remarked that in the case of municipal corporations the de facto doctrine is often resorted to. See note in 15 L. R. A. (N. S.) 94-107.

${ }_{15}$ See note 13. See also Pearl River County v. Lacey Lmbr. Co., (1921) Miss. 86 So. 755; Board of Highway Commissioners v. Bloomington, (1912) 253 Ill. 164, 97 N. E. 280, Ann. Cas. 1913 A 471; State v. Several Parcels of Land, (1907) $78 \mathrm{Neb} .703,111$ N. W. 602 (Enjoining tax). In Dennison IIfg. v. Wright, (1923) Ga. 120 S. E. 120, the court held that the taxes could be recovered from the collector when they were paid under protest, because the protest was said to constitute notice to the collector that he pays away the taxes at his own peril, for he knows they will be contested. The collector is given this consolation, "Besides, should there be any recovery against the defendant, the legislature should and doubtless will, reimburse the defendant, as the state has received the money raised by the exaction of this tax." Several cases are reviewed in the course of the opinion.

${ }^{10}$ See Tuttle v. Everett, (1875) 57 Miss. 27, 24 Am. Rep. 622; Detroit $v$. Martin, (1876) $34 \mathrm{Mich}$. 170, $22 \mathrm{Am}$. Rep. 512, for an example of payment to prevent sale of land, held voluntary. See Cooley, Taxation (3ed.) p. 1496, note 1 , and p. 1495. Bonds issued by a municipality under an unconstitutional statute have been held void even in the hands of an innocent purchaser. State v. Breckler, (1925) Wis. 202 N. W. 144. It has been said that an assessment levied under an unconstitutional statute does not create even an "apparent lien" and therefore no cloud on the title. Heywood v. City of Buffalo, (1856) 14 N. Y. 534. 
An interesting application of this doctrine that an unconstitutional statute is "fatally smitten at its birth" 17 is to be found in those cases where a person seeks to enjoin the threatened enforcement of some state statute which he alleges to be unconstitutional. The defence was often interposed in these cases that this was in effect a suit against the state and therefore within the prohibition of the eleventh amendment to the United States Constitution. The federal courts have held however, that these suits are not prohibited by that amendment and have enjoined the threatened enforcement of the state statutes under proper circumstances. ${ }^{18}$ In reaching this result the courts have reasoned that if the statute is unconstitutional it must fall. When the statute falls the defendant officers are left "standing naked, as individuals clothed with no power emanating from the state, and thus viewed and considered alone as individuals assuming to act under the guise of law where no law exists; . . . "10 And of course it follows in a most satisfactorily logical manner that the person threatening irreparable damage may be restrained in his private capacity.

It must not be imagined from the foregoing statements that all of our courts are in agreement as to the effect of unconstitutionality. Thus far we have examined situations in which there has been no particular conflict amongst the courts as to the effect of unconstitutionality. But so soon as we pass to the other situations which have been presented to the courts involving this point we find the decisions in conflict. The cases thus far have illustrated the view that a statute is absolutely void and never had any legal existence and that consequently any acts done in reliance on such an unconstitutional statute are not protected in any way. Neither the statutes nor acts done under them have any legal sanction under this view.

Take for example the question whether an unconstitutional bounty statute leaves a sufficient moral or equitable obligation on the state to justify the appropriation of public moneys which have been raised by taxation. Some courts have held that such an appropriation is constitutional when the object of it is to recompense officers or private individuals who have suffered because of the statute. ${ }^{20}$ Other courts have refused to uphold such an appropriation because they insist that no moral obligation can be raised by an unconstitutional statute. ${ }^{21}$

17 Ex parte Bockhorn, (1911) 62 Tex. Cr. 651, 138 S. W. 706.

$18 \mathrm{Ex}$ parte Young, (1907) 209 U. S. 123, 38 S. Ct. 441, 52 L. Ed. 714, 13 L. R. A. (N. S.) 952; Philadelphia Co. v. Stimson, (1912) 223 U. S. 605, 32 S. Ct. 340, 56 L. Ed. 570; West. Union Telg. Co. v. Myatt, (1899) 98 Fed. 355. See 43 AM. L. REv. 770 on the origin of the so-called "stripping doctrine". See also Saratoga, etc., Corp. v. Pratt, (1920) N. Y. 125 N. E. 834.

19 Kans. Natural Gas Co. v. Haskell, (1909) 172 Fed. 555.

20 U. S. v. Realty Co., (1896) 163 U. S. 427; Miller v. Dunn, (1887) 72 Cal. 462, 14 P. 27, 1 A. S. R. 67.

21 Mich. Sugar Ref. Co. v. Auditor Genl., (1900) 124 Mich. 674, 83 N. W. 625, 56 L. R. A. 329, 83 A. S. R. 359; Minn. Sugar Co. v. Iverson, (1903) 91 Minn. 30, 97 N. W. 454, criticizing U. S. v. Realty Co. cited in note 20. 
The Louisiana court has decided that an unconstitutional statute cannot ereate a natural or conscience obligation under the provision of the Code governing those obligations. ${ }^{22}$ On the other hand it was held in Arkansas recently that the fact that work was done under an unconstitutional statute does not prevent recovery from a road district on quantum meruit. . $^{3}$

Another point on which the courts are in conflict is the effect of an unconstitutional statute which purports to create a public office. In the leading case on this subject, Norton $v$. Shelby County, ${ }^{24}$ Justice Field said,

"An unconstitutional act is not a law; it confers no rights; it imposes no duties; it affords no protection; it creates no office; it is, in legal contemplation, as inoperative as though it had never been passed."

While this probably represents the weight of authority on this point of law, there is nevertheless considerable authority which holds to the contrary. In Kentucky it has been held that a judge appointed under an unconstitutional statute is a de facto officer and that his acts are valid until the unconstitutionality of the statute has been declared. ${ }^{25}$ And in a Mraine case a special attorney who was appointed for the state under an unconstitutional statute was held to be a de jure officer and his acts were to be treated as valid because they were said to have been done with color of authority. ${ }^{28}$ In the course of the opinion in the last cited case the court quoted with approval the following statement from Lang $v$. the Mayor, ${ }^{2 \pi}$ which is perhaps the leading case in opposition to Norton $v$. Shelby County referred to above,

"Every law of the Legislature, however repugnant to the Constitution, has not only the appearance and semblance of authority, but the force of law."

Here we have set forth a doctrine that a statute which is declared unconstitutional is inoperative only from the time of the decision and not from the time of its purported enactment. This view is of course opposed to the views expressed by the Indiana court in the cases cited in the first paragraph of this paper.

22 Factors and Traders Ins. Co. v. City of New Orleans, (1873) 25 La. Ann. 454.

${ }^{23}$ Road Improvement Dist. No. B v. Burkett, (1924) Ark. 260 S. W. 718.

24 (1886) 118 U. S. 425,6 S. Ct. 1121, 30 L. Ed. 178. On this question see note 8 Mich. L. Rev. 229; 15 L. R. A. (N. S.) 94; Mechem, Public Officers, sec. 324 note 3 , and sec. 326 . It seems that the distinction which is drawn in some of these cases is that in the case of municipalities the corporation is not created by the unconstitutional statute, but that its status or creation may not be challenged except by the state. See also Van Slyke v. Trempealeau, etc., Ins Co., (1876) 39 Wis. 390, 20 AM. REP. 50 and note.

${ }_{25} \mathrm{Nagel} v$. Bosworth, (1912) $198 \mathrm{Ky} .897,147$ S. W. 940.

26 State v. Poulin, (1909) $105 \mathrm{Me} .224,74$ A. 119.

${ }^{27}$ Lang v. Mayor of Bayonee, (1907) 74 N. J. L. 455, 68 A. 90, 15 L. R. A.

N. S.) 94 . 
There is perhaps no instance where these two views come into clearer relief or sharper conflict than in the type of case of which the famous Indiana case of Sumner $v$. Beeler ${ }^{28}$ is an illustration. In the case of Sumner v. Beeler the plaintiff had been arrested under a statute which the court decided to be unconstitutional. It is not possible to tell for a certainty whether the arrest had been made before the statute had been declared unconstitutional or not, but the court seems to assume that it was, and writers have assumed that such was the case ${ }^{20}$ The defendant officer was held liable in an action for damages. In the course of its opinion the court said,

"All persons are presumed to know the law, and if they act under" an uneonstitutional enactment of the legislature, they do so at their own peril, and must take the consequences."

Two cases from other jurisdictions in which there was no doubt but what the acts complained of were committed before the statute was declared unconstitutional will serve to further illustrate the application of the doctrine of the Beeler case. In Campbell v. Sherman,, ${ }^{30}$ the Wisconsin court was asked to pass upon these facts. The defendant sheriff (acting through a deputy) seized a steamboat belonging to the plaintiff under a writ from the Circuit Court of the state for the purpose of enforcing a maritime lien. The steamboat was destroyed by fire. The statute which authorized the issuance of the writ was declared unconstitutional. In an action for unlawful seizure and conversion the sheriff set up as a defence the statute which had been relied on in the proceedings. The officer was held not to have any defence. In the Massachusetts case of Kelly v. Bemis, ${ }^{31}$ a Justice of the Peace issued a mittimus under a statute which was later held unconstitutional. The Justice of the Peace was held liable in an action in trespass.

In an Iowa case $^{32}$ however, the court held that in such a situation as that involved in the Massachusetts case last mentioned the Justice of the Peace was not liable for a mistake in judgment as to the constitutionality of a statute. And in the Washington case of shafford $v$ Brown, ${ }^{33}$ a fruit inspector destroyed apples under the authority of an unconstitutional statute. He was held not liable in a subsequent action by the owner of the apples. In accordance with the two views set forth above regarding the liability of officers there are two lines of cases on the liability of individuals for their acts in aiding an officer who acts under an unconstitutional statute. ${ }^{34}$

28 (1875) 50 Ind. 341.

29 See note 64 AM. Dec. 51, Cooley, Constitutional Limitations, (5ed.) p. 224.

30 (1874) 35 Wis. 103.

31 (1855) 4 Gray 83, 64 Am. Oec. 50.

32 Henke v. McCord, (1880) 55 Ia. 378, 7. N. W. 623.

33 (1908) 49 Wash. 307, 95 P. 270.

34 See Cartwright v. Canode, (1914) 106 Tex. 502, 171 S. W. 157, holding they are liable. But see Dexter $v$. Alfred, (1892) 64 Hun. 36, 19 N. Y. S. 
But an officer who acts under an unconstitutional statute is not criminally liable. ${ }^{35}$ And this decision is not rested upon the lack of criminal intent, but rather upon the effect of unconstitutionality. A private person seems, however, to have been held liable in a criminal action for acts committed under an unconstitutional statute. ${ }^{36}$

One of the reasons assigned by the courts who hold the officer civilly liable in these officer cases is that noted in connection with Sumner v. Beeler, that everybody is presumed to know the law. A query might be raised whether this maxim refers to a knowledge of the rules of law or whether it also extends to a knowledge of what the courts are going to decide. One may know the rules of law very well but still guess wrong on the question of whether a court was going to hold a particular statute constitutional or unconstitutional. In other words, does the term "law" as used in this maxim include judicial decisions?37 Another point that is sometimes stressed is that of a writ or statute being clear on its face, either clearly valid or clearly invalid. When this test is attempted to be applied to the constitutionality of statutes one is immediately struck with the futility of such a test. When three judges hold it clearly unconstitutional, or vice versa, does this not seem to be hairsplitting? Another reason sometimes advanced in the cases is that the executive and legislative departments of the government are circumseribed by constitutional limitations and that one of the reasons for such limitations is to protect the rights of the individual against just such excesses of authority as are involved in these cases. The feeling that the executive department of the government was the personification of tyranny was still strong in the minds of the people and the courts during the last century and is not yet wholly eradicated. The founders of the state governments put their faith in the legislatures but a century of experience has resulted in a very considerable distrust of them also, as is reflected

770 , where the court said, "It is true that, as a general rule, ignorance of law cannot be urged as an excuse for a wrong, but we think in this case that it was competent for the defendant to set up, as a defense or partial defense to this action, the acts of the commissioner under this statute and that the acts done by the defendant were done under the direction or orders of the commissioner." It has been held that a person who takes land under a statute granting him the power of eminent domain is liable in an action for trespass if the statute turned out to be unconstitutional. Titus $v$. Poland, (1923) Pa. 119 A. 540. Of course a person who commits an act in reliance on the statute when that statute has previously been held invalid is subject to suit, as where hogs are impounded under a statute which had been declared unconstitutional. Nass v. Maxwell, (1895) 32 S. W. 561.

35 State v. Goodwin, (1898) 123 N. C. 697.

${ }^{38}$ Flaucher v. Camden, (1893) 56 N. J. L. 244, 28 A. 82. But see Strong v. Daniel (1854) 5 Ind. 348.

37 See for an example of where the rule is not applied so as to include a knowledge of overruling decisions or later decisions, 20 ENG. AND AM. ENCY. 2ed. p. 818. 
by the detailed bill of rights and other numerous procedural and financial restrictions imposed upon the legislative department by almost every state constitution. The courts very naturally have come to regard themselves as the guardians of the rights of the people which are in constant danger of being invaded by the legislature or the executive.

The courts which refuse to hold officers civilly liable in the above mentioned situations argue that a statute should be presumed to be constitutional until it is declared to be otherwise. They call attention to the statements made by practically every court to the effect that they will not pass upon the constitutionality of statutes unless it is essential to the disposition of the case in hand and that they will regard the statute as constitutional until its unconstitutionality is demonstrated beyond a reasonable doubt. ${ }^{38}$ These courts insist that this so-called presumption should mean something and that not only the judgse are to have the benefit of it. After all, does it not seem sound to give private individuals and ministerial officers the benefit of the view that statutes are to be obeyed until they are declared unconstitutional? Is this not especially so when one remembers that hundreds of statutes are declared unconstitutional because of technical or procedural defects, and not because they violate the rights of individuals. This was the case in Sumner $v_{n}$ Beeler, for there the sheriff had not guessed that the title was defective when compared with the body of the statute. ${ }^{39}$

We do not allow private individuals to resist an unconstitutional statute vi et armis, ${ }^{40}$ and in many states we do not allow ministerial officers to question the statute in defending against amndamus proceedings. ${ }^{41} \mathrm{He}$ is held liable if he acts under a statute which turns out

3s See for example the remark of Collins, J. in Allison v. Corker, (1902) 67 N. J. L. 596, 52 A. 362, 60 L. R. A. 564, when he says, "An unconstitutional statute is not merely blank paper. The solemn act of the Legislature is a fact to be reckoned with." See also the opinion of Chief Justice Gummere, in Lang v. Mayor, etc., cited in note 27. On the doctrine of reasonable doubt see Cushman, Constitutional Decisions by a Bare Majority of the Court, 19 MICE. L. REV.

39 See State v. Young, (1874) 47 Ind. 150.

${ }^{40}$ See State v. Skinner, (1900) La. 86 So. 716. However, in Cooley, Constitutional Limitations, (7ed) p. 259, note 2, Strong v. Daniel, (1854) 5 Ind. 348 , is cited in support of a statement that persons who have refused obedience to an unconstitutional statute are not protected. This was not a criminal case, however, but a case in equity. An injunction was issued in that case to prevent the execution of a judgment on a replevin bond which had been given under an unconstitutional statute.

41 On this point see note, 47 L. R. A. 512 for a full review of the cases pro and con. See also Collier, Unconstitutionality as a Defence to Mandamus Against Public Officer Refusing to Enforce Said Statute, 72 CENT. L. J. 301 criticizing several cases denying such defence, See also note, 64 Am. Dec. 51. On personal interest of the officer, see Braxton County Ct. $v$. 
to be unconstitutional, and he is liable if he refuses to act when the statute turns out to be constitutional.42 One cannot but feel that the officer gets the worst of it whichever way he turns. On the other hand, the judges of the courts of general or appellate jurisdiction are not liable for a mistake in judgment as to the constitutionality of a statute. $^{43}$ On the whole, the writer cannot help but feel that the suggestions made by a note writer in this connection are sound when he says 1. the statute should be presumed to be constitutional, 2 . that the statute should be obeyed by individuals and officers till it is declared unconstitutional, 3. that if there is anything in the nature of the office or of personal interest to entitle him to it, the officer should be allowed to question the statute. ${ }^{44}$ Should we not cease regarding the legislature with such suspicion and let those persons whose rights are alleged to be violated assert the unconstitutionality of the statute? So far as the courts are concerned the government now starts the race with a handicap. It is submitted that the cases opposed to Sumner v. Beeler embody the sounder rule.

There still remain a number of situations in which the application of the theory that the statute is void $a b$ initio should be tested.

1. Suppose a case where the court declares a statute unconstitutional today, and then six months hence reverses this decision and decides that the statute is constitutional. If the void $a b$ initio doctrine be applied the first decision would leave a situation similar to that de-

W. Va., (1908) 208 U. S. 192, 28 S. Ct. 275,52 L. Ed. 450. In Bd. of Liquidation v. $11 c \operatorname{Comb}$, (1875) 92 U. S. 531, 23 L. Ed. 623, the United States Supreme Court said, "In either case, if the officer plead the authority of an unconstitutional law for the non-performance or violation of his duty, it will not prevent the issuing of the writ. An unconstitutional law will be treated by the courts as null and void." And again, in Huntington $v$. Worthen, (1886) 120 U. S. 93, 30 L. Ed. 588, the court said, in discussing a complaint that the board of assessment commissioners had not complied with a statute which was claimed to be unconstitutional, "When, therefore, under the advice of the Attorney-General, the board or railroad commissioners treated as invalid the direction of the statute . . . it obeyed the Constitution rather than the Legislature. It may not be a wise thing, as a rule, for subordinate executive and ministerial officers ot undertake to pass upon the constitutionality of legislation prescribing their duties, and to disregard it if in their judgment it is invalid. . . . but still the determination of the legal tribunals can alone settle the legality of their action." The court warns also, that inconvenience to the public and risk to themselves might result if officers were to set themselves up as judges of the validity of the statute.

42 Clark v. Miller, (1874) 54 N. Y. 528.

43 On the topic of liability in general as applied to judicial officers, see Biddle, Liability of Officers Acting in a Judicial Capacity, 15 AM. L. Rev. 427, 492, reviewing fully the English and earlier American cases; Note, 14 L. R. A. 138. See also note, 64 AM. DEc. 61. See also Burdick, Torts, (Bed.) 35; Burdick, Law of the American Constitution, 123.

14 See note 64 Am. Dec. 51. See also note in 19 H. L. R. 352 which upholds the view of the cases opposed to the Beeler case. 
scribed by the Indiana court, as though no statute had been passed. The first question that arises then is how does it happen that there is any statute for the court to consider in the second case? The second point which presents itself is what happens to the statute under the second decision if it be regarded as still on the statute books after the first decision? All courts seem to agree that the void statute (if such a contradiction be permitted) is resurrected and is effective as from the date of its enactment. ${ }^{45}$. The purported enactment which was said to have been fatally smitten at its birth by the constitution has by some legal hocus pocus been cured of its congenital disease. This is also the Indiana rule. ${ }^{46}$

2. Suppose on the other hand a case in which a statute is declared to be constitutional today. Six months hence it is held to be unconstitutional. If the doctrine of void $a b$ initio be applied the statute should be rendered inoperative from the date of its attempted passage by the legislature. But let us suppose in addition in this case that a municipality had floated a bond issue which had been sustained by the first decision. In handling this sort of a. situation the federal courts have held that the statute is to be regarded as constitutional so long as the decision sustaining the statute was in force. Rights which have vested in reliance thereon may not be divested by the second decision. ${ }^{47}$ The second decision renders the statute inoperative only frum the date of that decision. At this point one wonders whether the Indiana court really meant what it said when it propounded the theory that in these cases of constitutional or unconstitutional statutes the court had nothing to do with the invalidating of the statute but merely expounded a fact which had always existed, namely, that the

45 Black, Constitutional Lavv, p. 75; Christopher v. Mungen, (1911) 61 Fla. 513, 55 So. 273 . In State v. O'Neil, (1910) 147 Ia. 513, 126 N. W. 454, $33 \mathrm{~L}$. R. A. 788, this state of facts was before the court. A statute was declared unconstitutional. $\mathrm{X}$ committed an act under it which would have violated it, had it been valid. Then the statute was held constitutional. Held, X not subject to prosecution.

46 Pierce v. Pierce, (1874) 46 Ind. 86. This case perhaps loses some of its force, however, because the statute which was involved in Langton $v$. Applegate, (1854) 5 Ind. 327 was not the same statute involved in Greenoastle So. Turnpike Co. v. State, (1867) 28 Ind. 382 . The Greencastle case reversed the Langton case, but the statutes before the court were not the same, although the same provision of the constitution was involved in both cases. The court in the Pierce case does not make any distinction on this basis however, and the case is usually understood to announce the same rule as those cases cited in note 45 .

${ }_{47}$ Gelpcke v. Dubuque, (1864) 1 Wall. 175, 17 L. Ed. 520; Los Angeles v. Los Angeles Water Co., (1899) 177 U. S. 558, 20 S. Ct. 736, 44 L. Ed. 886. These cases are severely criticized by several eminent writers on several grounds. See 1 Willoughby, Constitutional Law, p. 10, and 2 Willoughby, Ibid., p. 922-24. See on this topic generally, Dodd, Impairment of the Obligation of Contract by State Decisions, 4 Ix.. L. REv. 155, 327. 
statute was contrary to the constitution. ${ }^{48}$ As indicated above, the Indiana court itself has changed its mind as to the meaning of at least one article of the constitution. To state the process in that way is stating it too simply. As pointed out so ably by another, ${ }^{49}$ the process of construction and interpretation are much more complicated than is indicated by the statement of the court alluded to above.

3. Suppose a state statute is declared to be contrary to the constitution of the United States. Then by subsequent action of congress the states are allowed to enter the previously prohibited field. If the statutes of the states on this point were to be considered in force it would seem that they must have been re-enacted. But the courts hold that they are revived without re-enactment by the state legislature. ${ }^{30}$ The courts point out that they cannot repeal statutes and that the statutes are not absolutely void, but remain on the statute books.

4. Suppose a statute which has been declared unconstitutional is amended by legislative action so as to eure the defect which was found in it. Will the statute then be in full force and effect? Or suppose it is the provision of the constitution which has been changed so that the statute would not contravene it in its new form. In the answers given to these two questions by the courts there is a conflict of decisions. Those courts who treat the statute as void $a b$ initio should naturally hold that subsequent statutory or constitutional changes cannot cure the defective statute. But they do not always seem to be consistent in this, and the cases divide into several illogical groups on these questions. ${ }^{51}$

48 Oolitic Stone Co. of Ind. v. Ridge, (1910) 169 Ind. 639, 91 N. E. 944. See to the same effect $E x$ parte Bockhorn, (1911) 62 Tex. Cr. 651, 138 S. W. 706 , where the court says that the decision of unconstitutionality " . . was a mere judicial declaration of a pre-existing fact." This probaly indicates what is meant by mechanical jurisprudence as that term is used by modern writers.

${ }^{49}$ Gray, The Nature and Sources of the Law, (2ed.) p. 171. That writer says in this connection, "A judge puts before himself the printed page of the statute book; it is mirrored on the retina of his eye and from this impression he has to reproduce the thought of the lawgiving body. The process is far from being merely mechanical; it is obvious how the character of the judge, and the case of his mind must affect the operation, and what a different shape the thought when reproduced in the mind of the judge may have from that which it bore in the mind of the lawgiver. This is true even if the function of the judge be deemed only that of attempting to reproduce in his own mind the thought of the lawgiver . . ."

50 This seems to be the effect of In re Rahrer, (1891) 140 U. S. 545, 11 S. Ct. 865, 35 L. Ed. 5727. See also Commonvealth v. Calhane, (1891) 154 Mass. 115, 27 N. E. 881; Stajar v. Dickinson, (1918) Ia. 169 N. W. 756; McCollum v. McConanghy, (1909) 141 Ia. 172, 119 N. W. 539.

51 See Ex parte Bockhorn, (1911) 62 Tex. Cr. 651, 138 S. W. 706; State v. Tuffley, (1890) 20 Nev. 427, 19 A. S. R. 374. Contra, State v. City of Cincinnati, (1895) 52 Oh. 419, 40 N. E. 508. See 38 L. R. A. (N. S.) 77-79. See Ross v. Bd., (1905) 128 Ia. 427, 104 N. W. 506, 1 L. R. A. (N. S.) 431. See also note, 60 L. R. A. 564. 
5. Let us consider two cases in the law of crimes. First, let us suppose that a person is convicted under an unconstitutional statute. We have noted previously that the usual result in such a case is to free the accused person. Now let us suppose that an indictment were brought against this person under a statute which is constitutional. $\mathrm{H}_{\mathrm{e}}$ sets up in defence his prior indictment and trial under the unconstitutional statute. It has been held that if he acquiesced in the first trial he may not be tried again, under the prohibition of double jeopardy. ${ }^{52}$ In the second place let us suppose that an insane person is committed under an unconstitutional statute. Is he set free when the unconstitutionality of the statute is determined? $\mathrm{He}_{\mathrm{e}}$ is not. ${ }^{.5}$ But is there really much more reason why an insane person should be restrained of his liberty under an unconstitutional statute than a murderer who pleads guilty? The latter escapes, but the former does not. Should not both of them be placed in such a position that they are no longer able to threaten the community? But the prize winning case in the realm of eriminal law seems to the writer to be that of In re Medley, ${ }^{54}$ wherein the prisoner was set free because a state statute which was declared to be unconstitutional because ex post facto was held to have repealed the previous state statute which had covered the subject. Here certainly is a repudiation of the void $a b$ initio and in toto theory with a vengeance.

From the above review of the eases involving the effect of unconstitutionality it will be seen that the courts usually choose one of two alternatives. They may follow strictly the view that an unconstitutional statute is void $a b$ initio and refuse to recognize the validity of any acts done in reliance on the statute. This sometimes leads to socalled strong decisions, decisions contrary to sense and justice. Or they may choose to modify the general rule which they may have previously enunciated, or refuse to apply it to a particular situation. There are two views that are discernible in the foregoing cases. One view is that just mentioned, that the statute is as though never passed. The other is that the statute is as though passed, is to be relied upon, and to be regarded as law until the statute is declared unconstitutional. There are some situations where the courts are willing to follow the void $a b$ initio doctrine, but they are not so very numerous. There are other situations in which the courts are in conflict whether the statute is to be treated as void from the beginning or not. Then there is

52 McGinnis v. State (1848) 9 Humph. (Tenn.) 43, 49 Am. Dec. 697.

${ }^{53}$ In re Boyett, (1904) 136 N. C. 415,48 S. E. 789,103 A. S. R. 944, 67 L. R. A. 972, 1 Ann. Cas. 729.

54 (1889) 134 U. S. 160, 10 S. Ct. 384, 33 L. Ed. 835. The court released the prisoner, because, ". . . it is apparent that while the statute under which is now held in custody is an ex post facto law in regard to his offence, it repeals the former law, under which he might otherwise have been punished 
another group of situations in which all courts refuse to adhere to the doctrine that the statute is void from the beginning. From this it can be seen that it is impossible to lay down as a general rule that an unconstitutional statute is void, or is to be treated as no law. As a matter of fact there are as many cases or more, and as many situations or more, where the courts hold the statute inoperative only from the date of the decision as there are that hold it void from the beginning.

There is, however, another phase of the subject which is suggested by the group of cases of which Shephard $v$. Wheeling ${ }^{55}$ is an example. In that case the court said,

". . it does not annul or repeal the statute if it finds it in conflict with the Constitution. It simply refuses to recognize it, and determines the rights of the parties just as if such statute had no existence. The court may give its reasons for ignoring or disregarding the statute, but the decision affects the parties only, and there is no judgment against the statute. The opinion or reasons of the court may operate as a precedent for the determination of other similar cases, but it does not strike the statute from the statute book; it does not repeal - . . the statute. The parties to that suit are concluded by the judgment, but no one else is bound. A new litigant may bring a new suit, based upon the very same statute, and the former decision cannot be pleaded as an estoppel, but can be relied on only as a precedent. This constitutes the reason and basis of the fundamental rule that a court will never pass upon the constitutionality of a statute unless it is absolutely necessary to do so in order to decide the cause before it."

In the opinion of the Indiana court in the case of Pierce v. Pierce, ${ }^{56}$ previously referred to, the court assumes that in the two previous cases which were discussed the same statute was involved. What actually happened was that in the first ease ${ }^{57}$ where the statute was declared unconstitutional there was a different statute involved than in the second case ${ }^{58}$ where another statute was declared constitutional. The court had before it in these two cases two different statutes, both containing the same defect, and both cases turned upon the construction of the same constitutional provision. The court construed the constitutional provision differently, not the statutes, in these two cases.

55 (1887) 30 W. Va. 479,4 S. E. 635. See this statement by the New Jersey court in Allison v. Corker, (1902) 67 N. J. L. 596, 52 A. 362, "An unconstitutional statute is nevertheless a statute; that is, a legislative act. Such a statute is commonly spoken of as void. I should prefer to call it unenforceable, because in conflict with a paramount law. If properly to be called void, it is only so with reference to claims based upon it." See also Rutten v. Mayor, etc., (1906) 73 N. J. L. 467, 64 A. 573; Bentley v. State $B d$. Medical Examiners, (1922) Ga. 111 S. E. 379. So a statute may be unconstitutional as to past transactions, but valid as to future ones, Harlee v. Ward, (1868) 15 Rich. Law (S. Car.) 231.

s6 (1874) 46 Ind. 86.

57 Langton v. Applegate, (1854) 5 Ind. 327.

${ }^{58}$ Greencastle So. Turnpike Co. v. State, (1867) 28 Ind. 382. 
Then in the Pierce case the court says that the rule is that where a statute which has been held unconstitutional is subsequently held constitutional, the statute is to be treated as a valid statute from the date of its enactment. This question was not presented by the facts of the case, however. It may be that the court was thinking in terms of the constitutional provision instead of in terms of the statutes involved.

This raises an interesting and somewhat important question. Suppose a statute is declared unconstitutional today. Is every statute on the books which contains that same infirmity to be deemed unconstitutional also? Or does the declaration of unconstitutionality affect only that particular statute which was before the court? There are cases which seem to imply as the Indiana ease does, that the broader effect is to be given to the decision. ${ }^{59}$ When one stops to analyze the decisions and the theories underlying them he is confronted with a considerable task. The usual explanation of the process of declaring statutes unconstitutional is that there is on the one side a body of paramount rules and principles. These are collectively denominated the constitution. Then there is another body of rules which are denominated statutes. It is not so important here whether we regard the constitution and statutes as law or as sources of law. ${ }^{60}$ In the decision of a given ease the courts must apply a rule. Here are two rules, or sources of rules. The rule found in the constitution must prevail. But the question still remains, what becomes of the other rule? Is it still a rule, only held in abeyance? Or is it entirely abrogated forever, unless the legislature which gave expression to it in the statute shall again express its will in another statute? It is quite clear why statutes are declared unconstitutional in many instances. But it is not so clear why it shall be said that the statute is entirely abrogated by a decision of a court that it is unconstitutional. Perhaps we will need to peer deeper to find the reason which caused the courts in the early cases to hold that the statute was void $a b$ initio. Law does not consist only of rules of conduct. ${ }^{61}$ But it so happens that it is this phase of the content of the term that we have in the recent past

59 See Commonwealth v. Calhane, (1891) 154 Mass. 115, 27 N. E. 881; Stajar v. Dickinson, (1918) Ia. 169 N. W. 756; MaCollum v. McConaughy, (1909) 141 Ia. 172, 119 N. W. 539.

${ }^{60}$ Gray, Nature and Sources of Law, (2ed.) p. 170, insists that constitutions and statutes are only sources of law. In Pound, Outlines of Lectures on Jurisprudence, (3ed.) p. 93, legislation is given as one of the forms of law.

61 For a convincing demonstration that this is so see Pound, The Theory of Judicial Decisions, 36 H. L. R. 641, 802, 940. "These three elements that make up the whole of what we call law are: (1) a number of legal precepts more or less defined, the element to which Bentham referred when he said that law was an aggregate of laws; (2) a body of traditional ideas as legal precepts should be interpreted and applied and causes decided, and a traditional technique of developing and applying legal precets whereby these precepts are eked out, extended, restricted, and adapted to the exigen- 
stressed the most. In the minds of many judges is often to be found the outline of an ideal pattern towards which they seek to make the law move. This is as it should be. Constitutional law and constitutional interpretation are often as much affeeted by the views we entertain on the subject of government as by our ideas of strict law. Is it not only reasonable to expect, therefore, that the judges will be influenced by their ideas of government in the making of decisions in this field? Could the human mind so operate as to exclude it? If there be any truth in this view it may be that here is some light on what caused the early courts to hold that the statute was not only inoperative from the decision, but from the time of purported enactment. The American ideal of government during the past century was and still is that there are three departments of government, each with its own functions and powers. The constitution prescribes the limits of each. Neither of them should overstep these limits. In these cases under review the courts find that the legislature or exeeutive department has overstepped its bounds. In an ideal system they would not do this, and so the judges in the early cases decided to treat these excesses as though they had never happened, because they should not have happened. The problem was viewed and treated as one of legislative power or capacity. This may offer a partial explanation for a rule which seems to be rather ill-suited to modern conditions. It is submitted that the view set forth in the Shephard ease, ${ }^{62}$ more nearly describes what actually takes place in the majority of situations which the courts meet in this branch of the law than do any of the other explanations offered.

In view of the cases reviewed above one is a little surprised to find the doctrine of void $a b$ initio stated as the universal and unqualified rule by so eminent an authority as Cooley, in his work on ConstiTuTronal Limitations, ${ }^{63}$

"When a statute is adjudged to be unconstitutional, it is as if it had never been. Rights cannot be built up under it; contracts which depend upon it for their consideration are void; it constitutes a protection to no one who has acted under it, and no one can be punished for having refused obedience to it before the decision was made."

That this statement is not in accord with the cases would seem clearly right from the above review of both federal and state cases. It illustrates, however, the persistence with which even eminent text writers will cling to the view that unconstitutional statutes are void $a b$ initio.

cies of administration of justice; (3) a body of philosophical, political and ethical ideas as to the end of law, and as to what legal precepts should be in view thereof, held consciously or subconsciously, with reference to which legal precepts and the traditional ideas of application and decision and the traditional technique are continually reshaped adn given new content or new application." p. 645. Each of the three articles deals with one of these elements.

02 See note 55 and cases.

63 (7ed.) p. 259 and note 2. Several of the cases cited in this note do not bear out the broad statement quoted above. 


\section{SUMMARY}

In summary the rules of law which have been followed by the courts in the cases reviewed in this article might be classified as follows:

I. Situations in which the court adheres to the view that the statute is void $a b$ initio.

1. The case of a repealing statute, except in the case of In re Medley.

2. An unconstitutional amendment to a statute.

3. Where eriminal conviction under an unconstitutional statute is reversed.

4. Judgment in eivil suit rendered under an unconstitutional statute or by a court which is established or granted jurisdiction by an unconstitutional statute, except as limited by the de facto officer doctrine.

5. Incorporation or disincorporation of a city, except as affected by the de facto doctrine.

6. Taxes paid under an unconstitutional statute may be recovered. This doctrine is curtailed in practical operation by the limitations enforced by the courts regarding voluntary payment.

7. The so-called stripping doctrine under the eleventh amendment to the United States Constitution.

8. Individual liability in criminal action for acts committed under unconstitutional statute.

II. Situations in which the courts are in conflict whether the rule should be that of void $a b$ initio or that of void from the date of the declaration of unconstitutionality by the court.

1. Unconstitutional statutes as creating a moral obligation on the government or on individuals.

2. Creation of a public office.

3. Liability of officers in civil suit for acts done in reliance on an unconstitutional statute.

4. Liability of individuals in civil action for acts done in reliance on an unconstitutional statute.

5. Defence of an officer to an action of mandamus to compel him to act under an unconstitutional statute.

6. Curing of the defect of unconstitutionality by a statutory amendment.

7. Curing defect of unconstitutionality by a change in the constitution.

III. Situations in which the courts refuse to apply the void $a b$ initio doctrine and apply the doctrine of void from the time of the declaration of unconstitutionality.

1. Criminal Liability of an officer who has acted under an unconstitutional statute. 
2. Reversal of a decision of unconstitutionality.

3. Reversal of a decision of constitutionality with rights acquired in reliance on first decision.

4. Criminal conviction under unconstitutional statute and double jeopardy and the commitment of an insane person under an unconstitutional statute.

IV. There is a fourth group of cases which hold that an unconstitutional statute is not void at all, but that the statute is only inapplicable to the particular situation presented to the court in a given case. The statute may be applicable to other situations and is therefore said to be constitutional as to them. 